\title{
Taxing a Digital Economy: \\ Exploring Intangible Assets to Broaden Revenue Base in Kenya
}

\author{
Fustice Gatuyu*
}

\begin{abstract}
The world economy has shifted from brick and mortar industries to a knowledge and service economy. In the age of digital evolution, intangible assets have become the new drivers of corporate profit and restructured business models of leading firms. Creators of these assets look forward to monetising and making gains from them. Equally, governments expect to extract revenues by way of taxation. As cross-border trade broadens with the rise of globalisation, intangible assets have increasingly become an area of concern in relation to tax avoidance schemes especially by global firms. In Kenya, appreciation of intangible assets has been rising. This study surveys the prospects of expanding Kenya's revenue base by tapping intangible assets. The digital economy in Kenya is generally inadequately regulated. This leaves tax loopholes which this study explores in order to identify where revenue can be imposed. In order to make recommendations, the study equally focuses on accounting, valuation, and transfer pricing of intangible assets for tax purposes. To this extent, numerous reforms are necessary to ensure that the taxation of intangibles is optimal and does not distort the rise of a digital economy.
\end{abstract}

Key words: Intangibles, Taxation, Intellectual Property, Digital economy.

\section{Introduction}

The twenty-first century has presented a quiet revolution. For the first time, major developed economies are investing more in intangible assets such

* The author is an Advocate of the High Court of Kenya an MSC (Tax Administration) student at KESRA. Contact: jgatuyu@gmail.com. 
as design, branding, software, research and development, than in tangible assets, such as machinery, buildings, and computers. For all sorts of businesses, from tech firms and pharmaceutical companies to coffee shops, the ability to deploy intangible assets has become a main source of long-term success. ${ }^{1}$ This growth of the digital economy is characterised by an unparalleled reliance on intangibles, the massive use of data, and widespread adoption of multi-sided business models capturing value from externalities generated by free products, and the difficulty of determining the jurisdiction in which value creation occurs'. ${ }^{2}$

The knowledge economy has occasioned rapid growth and investment in intangible assets which have exceeded their traditional capital in leading global firms. ${ }^{3}$ Intangible assets (herein referred to as 'intangibles') have consequently become a major source of sustainable competitive advantage for many firms and their importance has been growing. ${ }^{4}$ The technology revolution has further made technologies cheaper and more powerful, enabling improvement of business processes and boosting innovation, consolidating intangibles as key profit drivers. ${ }^{5}$

Intangibles are assets that do not have a physical or financial embodiment. They are broadly classified into 'trade intangibles' and 'marketing intangibles'. Trade intangibles such as know-how relate to the production of goods and the provision of services and are developed through research and development. ${ }^{7}$

Marketing intangibles, such as trade names, trademarks and client lists, aid in the commercial exploitation of a product or service. ${ }^{8}$ The two categories have elements of computerised information such as software and databases, innovative property, goodwill and economic competencies which includes brand equity. ${ }^{9}$

Intangible assets have different economic characteristics from tangible investment which has traditionally predominated and is more scalable. For

Haskel J and Stian W, Capitalism without capital: The rise of the intangible economy, Princeton University Press, New Jersey, 2018, 2.

2 OECD Base Erosion and Profit Shifting Project, Action Plan 1: Addressing the tax challenges of the digital economy, 2015, Final Report.

3 King K, 'The value of intellectual property, intangible assets and goodwill' 7 (1) Journal of Intellectual Property Rights, 2002, 245-248.

Haskel J and Stian W, Capitalism without capital: The rise of the intangible economy, 2.

United Nations, Practical manual on transfer pricing for developing countries, 1.

King K, 'The value of intellectual property, intangible assets and goodwill', 246.

Gatuyu J 'Let's tap intangible assets to broaden tax base' Business Daily, 19 February 2018.

United Nations, Practical manual on transfer pricing for developing countries, 2018, 1.

King K, 'The value of intellectual property, intangible assets and goodwill', 246. 
instance, the Coca Cola Company is responsible for only a limited number of products, but its most valuable assets are brands, licensing agreements, and the recipe of the Coke syrup. Coca Cola's intangible assets have been scaled across the world. ${ }^{10}$ Intangibles are able to restructure business models of global firms, by enabling differentiation between products hence facilitating product growth and profits. ${ }^{11}$

Powerhouse companies such as Google, Amazon, Facebook and Apple have structured their business models around intangibles and digital assets and laid foundation to their market dominance and continued profitability. ${ }^{12}$ The ability to scale intangibles has been a contributor to an increasing enterprise value of many global firms. ${ }^{13}$ For instance, Figure 1 illustrates the gradual growth and contribution of intangibles in comparison to tangibles on market capitalisation of S\&P 500 firms in the United States. ${ }^{14}$

Figure 1: Growth of intangible and intangible assets in S\&P firms in United States from 1975 to 2010

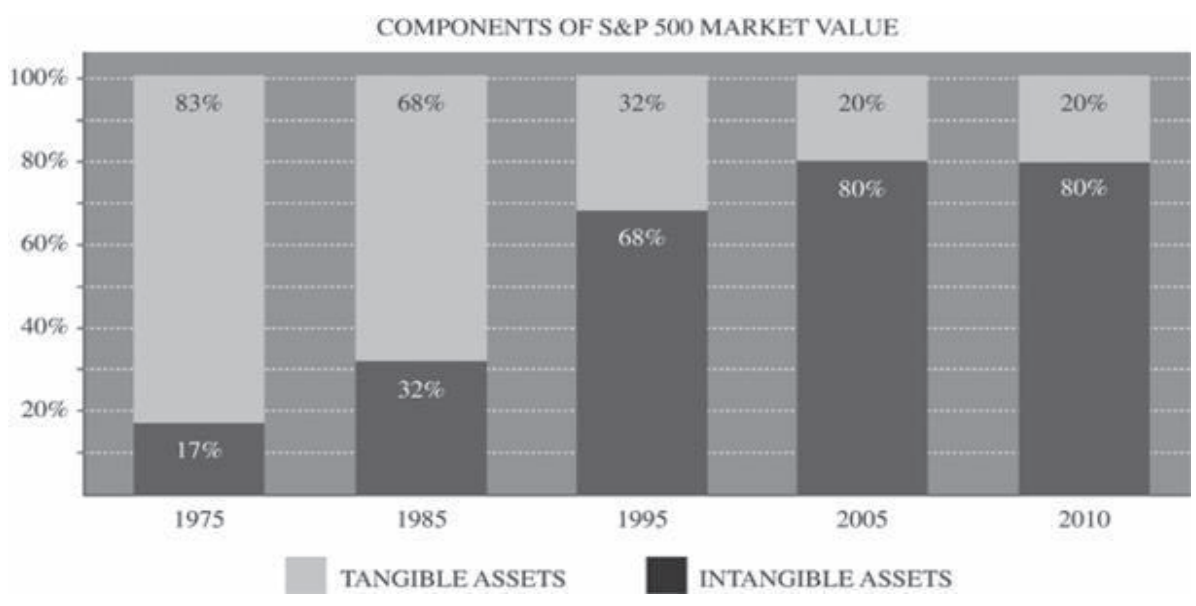

10 Haskel J and Stian W, Capitalism without capital: The rise of the intangible economy, 9.

11 Petkova L, 'Tax Treatment of Intangible Assets' Bulgaria Ministry of Finance, June $2010<$ https:/ / www.minfin.bg/upload/10799/Tax_treatment_of_intangible_assets.pdf $>$ on 12 November 2018.

12 <https://www.coursera.org/learn/international-taxation/lecture/v8x83/apple-case $>$ on 7 November 2018.

13 Sinclair R and Lane $\mathrm{K}$, 'Towards integrated reporting - Communicating value in the 21st century' International Integrated Reporting Committee, 2011, 10-17. -<http://integratedreporting.org/wpcontent/uploads/2011/09/IR-Discussion-Paper-2011_spreads.pdf $>$ on 12 November 2018.

14 Sinclair $\mathrm{R}$ and Lane K, 'Towards integrated reporting - Communicating value in the 21st century', 10-17. 
In Kenya, Safaricom Limited reported the value of its intangible assets as at March 2017 to be Kshs 10 Billion, entailing goodwill and network licenses. Notably, the value of Safaricom's intangibles is more than the value disclosed for share capital reported at Ksh 2 Billion. ${ }^{15}$ Further, the company has a liability of Ksh 3.3 billion occasioned by intangibles in the nature of Bonga Points, a type of customer loyalty award scheme. ${ }^{16}$

Unique forms of intangibles have arisen with the general expansion of the cyberspace. These include virtual assets and digital 'currencies' such as Bitcoin. They also exist in virtual computer-generated worlds, such as City of Heroes and World of Warcraft, adventure games involving quests, raids and fights, where participants may end up often receiving items, such as armour, and other virtual assets with a value within the game that are still able to be cashed in the real world. Some of these unique forms of intangibles have high values. As the value of intangible assets ascends, creators and holders are eager to commercialise their rights to enjoy financial returns. Similarly, revenue authorities are eager to tap into this growth to broaden their revenue base. ${ }^{17}$

In order to navigate the taxation terrain, most global firms, especially the so-called 'tech giants', have resorted to creating complex corporate structures to hold their intangibles, including the use of a licensing route to transfer intangibles to low tax jurisdictions, leading to the rise of patent boxes and preferential tax regimes. ${ }^{18}$ These tax avoidance tactics erode taxable base of the companies, and governments are deprived of revenue opportunity.

The dilemma of policymakers is with regard to the mechanism that could be explored to tap into the growing regime of intangibles by way of taxation in order to broaden the revenue base. This is doable, but various reforms are required concerning tax principles and transfer pricing. Nevertheless, even as governments seek to extract revenue from the growing value of intangibles, balance ought to be created to promote these assets through incentives geared towards stimulating research and development.

The objective of this study is to explore a mechanism of tapping revenue from intangible assets. As an overview, Part I acts as the introduction of the study giving a brief on the issue of taxation of intangible assets. Part II of the study analyses the characterisation and accounting of intangible assets with the aim of

\footnotetext{
Safaricom Limited, Annual Report: Statement of Financial Position, 2018, 109.

Mugambi M, 'Safaricom bonga points up 2.8pc to Sh3.3 billion, Business Daily, 24 August 2017.

Gatuyu J, 'Let's tap intangible assets to broaden tax base', Business Daily, 19 February 2018.

Practical manual on transfer pricing for developing countries, 3.
} 
outlining the nature of intangibles in terms of acquisition, commercialisation, valuation and amortisation. Part III reviews the regulatory framework that anchors intangible assets aimed at determining a legal basis of intangibles. Part IV explores tax treatment of intangibles from various tax heads, addresses transfer pricing concerns and reviews proposals contained in the Income Tax Bill 2018. Part V makes closing remarks by reconciling various discussion points and further makes necessary policy recommendations to facilitate tapping into intangible assets to broaden revenue base in Kenya and other developing economies.

\section{Characterisation and Accounting for Intangibles}

Factors to consider when characterising and accounting for intangible assets include their nature, modes of acquisition and commercialisation, and, lastly, techniques for valuation and amortisation. This part interrogates these aspects.

\section{i. $\quad$ The nature of intangible assets}

Recognising something as an intangible for legal or accounting purposes is an informative starting point, even though not determinative. The term 'intangible' sounds understandable in a literal sense. However, there has been no universal definition on what constitutes intangible assets. This has often inflamed disputes between taxpayers and tax administrations. ${ }^{19}$

The International Accounting Standard (IAS) 38 describes intangible assets as 'non-monetary assets which are without physical substance and identifiable, either separable or arising from contractual or other legal rights. ${ }^{20}$ To this extent, for purposes of accounting, intangible assets have to be clearly identifiable and meet relevant recognition criteria. IAS 38 further provides guidance on the recognition, acquisition and measurement of intangible assets. The criterion for recognition includes the expected future economic benefits flowing in the entity being attributable to the asset and the cost of the intangible being able to be measured reliably. ${ }^{21}$

\footnotetext{
19 Manzoor L, 'Levy of income tax on intellectual property' SSRN, $2013<$ https://ssrn.com/ abstract $=2400900>$ - on 6 November 2018 .

20 International Accounting Standards (IAS) are issued by the International Accounting Standards Board (IASB) to guide the practice of accounting.

21 Article 124, International Accounting Standards.
} 
The OECD provides that an intangible asset is an asset that is neither a physical nor a financial instrument, but one capable of being owned or controlled for commercial purposes, whose use or transfer would have been compensated had it occurred between independent enterprises in comparable circumstances. ${ }^{22}$ The Supreme Court of India once observed that goods can be either tangible or intangible, a test to this being whether a concerned item is capable of abstraction, consumption and use, and whether it can be transmitted, transferred, delivered, stored, and possessed. ${ }^{23}$

Generally, intangible assets have often been characterised either as goodwill or fall into one of the following five categories. The first category is marketingrelated intangibles: These are used primarily in the marketing or promotion of products or services. Examples include trademarks, trade names, and unique trade design and internet domain names. The second category is customerrelated intangibles: These include customer lists, backlog, customer contracts, and contractual and non-contractual customer relationships. Artistic-related intangibles form the third category. These arise from the right to benefits such as royalties from artistic works such as plays, books, films and music, and from non-contractual copyright protection. The fourth type is contract-related intangibles. These represent the value of rights that arise from contractual agreements. Examples include licensing and royalty agreements, service or supply contracts, lease agreements, permits, broadcast rights, servicing contracts, noncompetition agreements and natural resource rights; and lastly are technologybased intangibles. These arise from contractual or non-contractual rights to use patented technology, unpatented technology, databases, formulae, designs, software, processes or recipes. ${ }^{24}$

Discernibly, an intangible asset is a resource that is controlled by the entity as a result of past events (such as purchase or innovation) and from which future economic benefits (inflows of cash or other assets) are expected. In summary, the critical attributes of an intangible are such asset being identifiable, separable (capable of being separated and sold, transferred, licensed, rented, or exchanged, either individually or together with a related contract) or that arises from contractual or other legal rights, regardless of whether those rights are transferable or separable from the entity or from other rights and obligations, control (power to obtain benefits from the asset), and future economic benefits

The OECD-BEPS, Final Report, October 2015.

Tata Consultancy Services v State of Andhra Pradesh (2004), Supreme Court of India.

Practical manual on transfer pricing for developing countries, 4 . 
(such as revenues or reduced future costs). ${ }^{25}$

Where an entity is not able to delineate and classify an intangible asset, such assets are recognised as goodwill. ${ }^{26}$ Goodwill, often referred to as the intangible of the intangibles', is identified with the business as a whole and can only be sold by selling the business. ${ }^{27}$

\section{ii. Acquisition}

An intangible asset may be acquired in numerous ways. These include by purchase, as part of a business combination, by a government grant, by exchange of assets, or by self-creation (internal generation). ${ }^{28} \mathrm{~A}$ discussion on the method used to acquire an intangible asset is important because it guides on recognition, valuation, and eventually impacts the tax treatment.

The most common method of acquiring intangibles is through purchase by a market transaction. In this, the cost includes the purchase price, duties and non-refundable purchase taxes, after deducting trade discounts and any rebates, directly attributable cost of preparing the asset for its intended use. ${ }^{29}$ The second method is acquisition by business combination, where an acquirer (entity) obtains control of one or more businesses. If an intangible asset is acquired in a business combination, the cost is its fair value at the acquisition date. ${ }^{30}$ Determining the proper cost to allocate to intangible assets in a business combination is complex because it is extremely difficult not only to identify certain types of intangibles but also to assign a value.

A third method of acquisition is through a grant. In cases where the grant is received from government, it is recognised and accounted for in accordance with the IAS 20, which guides on accounting for government grants and disclosure of government assistance. ${ }^{31} \mathrm{~A}$ fourth method is through an exchange of assets. In this case, the intangible asset is acquired in exchange for another asset. The cost

25 Reilly R and Schweihs R, 'Intangible assets' in Reilly R, Schweihs R (eds) Intangible Assets, guide to intangible assets valuation revised edition, Wiley publishers, London, 2016.

26 Reilly R and Schweihs R, 'Intangible Assets,' 30.

27 Reilly $\mathrm{R}$ and Schweihs R, 'Intangible Assets,' 31.

28 King K, 'The value of intellectual property, intangible assets and goodwill', 4.

29 Manzoor L, 'Levy of income tax on intellectual property' SSRN, $2013<$ https://ssrn.com/ abstract $=2400900>$ - on 6 November 2018 .

30 Fair value is the amount for which an asset could be exchanged between parties in an arm's length transaction.

31 IAS 20, Accounting for government grants and disclosure of government assistance, IASB 1983 <https://www.iasplus.com/en/standards/ias/ias20> on 18 November 2018. 
in such instance is measured at fair value unless the exchange transaction lacks commercial substance or the fair value of the asset received or the asset given up is reliably measurable. If the acquired asset is not measured at fair value, its cost is measured at the carrying amount of the asset given up. ${ }^{32}$

Lastly, intangible assets such as brands and customer lists could be internally generated through research and development within an entity. The cost of an internally generated intangible asset comprises all directly attributable costs necessary to create, produce, and prepare the asset to be capable of operation in intended manner. ${ }^{33}$ The American accounting rules abhor the practice of accounting for brands that are internally generated intangibles, but there has been a clamour to change such views. ${ }^{34}$

Whatever method of acquiring an intangible asset is employed, it is recognised if the expected future economic benefits or service potential that is attributable to the asset will flow to the organisation and the cost of the asset can be measured reliably. ${ }^{35}$ If this criterion is not met, then the cost of such intangible should be fully expensed in the financial period when it was incurred.

After initial recognition, the asset is carried at historical cost less accumulated amortisation and any impairment losses. Where an intangible asset is acquired at no cost or for a nominal cost, the fair value of the asset as at the date of acquisition is used. ${ }^{36}$ As this study will later discuss, the mode of accounting treatment of an intangible asset during acquisition has tax implications and is critical for transfer pricing analysis.

\section{iii. Commercialisation}

After acquisition of an intangible, the next process is to create utility and monetise the asset. ${ }^{37}$ Commercialisation is a continuum of activities and actions that provides for the protection, management, evaluation, development and value-creation resulting in economic and societal benefits. ${ }^{38}$

32 Petkova L, 'Tax Treatment of Intangible Assets' Bulgaria Ministry of Finance, June $2010<$ https:// www.minfin.bg/upload/10799/Tax_treatment_of_intangible_assets.pdf> on 12 November 2018.

33 Petkova L, 'Tax Treatment of Intangible Assets’ Bulgaria Ministry of Finance, June $2010<$ https:// www.minfin.bg/upload/10799/Tax_treatment_of_intangible_assets.pdf> on 12 November 2018.

34 'Accounting for brands untouchable intangibles', Economist, 30 August $2014<$ https://www. economist.com/business/2014/08/30/untouchable-intangibles> on 12 November 2018.

35 United Nations, Handbook on IPSAS Guidelines and Policy, 11 November 2018.

36 United Nations, Handbook on IPSAS Guidelines and Policy, 11 November 2018.

${ }_{37}$ King K, 'The Value of intellectual property, intangible assets and goodwill', 247.

${ }_{38}$ King K, 'The Value of intellectual property, intangible assets and goodwill', 247. 
One of the commercialisation methods includes internal development, also known as value creation, where the inventor further develops the asset through research and development. It could be conducted through an incubator and supported through accelerator programmes. ${ }^{39}$ An incubator is a facility that houses multiple start-up inventions while accelerators have evolved as a resource for the expanded services provided to start-up companies including support with technology transfer, partnering, business development, and are often affiliated with acquiring start-up funding for companies..$^{40}$

Joint ventures and partnering is another common commercialisation method. This is a collaborative partnership between a company that holds the license to the intangible and another that is able to commercially exploit it. ${ }^{41}$ Alternatively, an entity can establish another special purpose vehicle to hold the intangible property to facilitate joint ventures with industry. ${ }^{42}$ This enables the attraction of resources and acceleration of development without encumbering the company's internal resources. Related to this is commercial licensing, where intangibles are leased to potential partners and customers for a consideration agreed in their contractual arrangements. ${ }^{43}$

Lastly, forming innovation ecosystems and clusters is another method. This is the mode of commercialisation associated with successful U.S. innovation zones such as Silicon Valley and Research Triangle Park, U.S. ${ }^{44}$ A cluster is a geographic concentration of interconnected businesses, suppliers, and associated institutions in a particular field. ${ }^{45}$ It enables the development of critical mass, a large enough concentration of companies to provide sharing of resources, secondary impact, and the attraction and development of new resources. ${ }^{46}$ Industrial clusters have

39 Amadala C, 'CMA to entice SMEs to list through accelerator' The Star, 4 August 2017

< https://www.the-star.co.ke/news/2017/08/04/cma-to-entice-smes-to-list-through-accelerator_ c1609858> on 6 November 2018.

40 National Research Council, 'Clusters and regional initiatives' in Wessner C, Wolff A (eds) Rising to the Challenge: U.S. innovation policy for the global economy, The National Academies Press, Washington, 2012, 431.

41 King K, 'The Value of Intellectual Property, Intangible Assets and Goodwill', 248.

42 King K, 'The Value of Intellectual Property, Intangible Assets and Goodwill', 248.

43 Stewart T, 'Your company's most valuable asset: Intellectual capital', Fortune, 3 October 1994, 68, $<$ http://archive.fortune.com/magazines/fortune/fortune_archive/1994/10/03/79803/index. htm>-on 12 November 2018.

44 National Research Council, 'Clusters and regional initiatives'.

45 Harvard Business School, 'What are clusters?'<https://www.isc.hbs.edu/competitivenesseconomic-development/frameworks-and-key-concepts/Pages/clusters.aspx> on November 13 2018.

46 Haskel J, 'Capitalism without capital the rise of the intangible economy', 9. 
been the subject of study by economist Alfred Marshall. ${ }^{47}$ Marshall identified three basic advantages of these clusters including pools of skilled labour; knowledge spill-overs; and inter-firm linkages. Regional innovation clusters have a proven track record of getting good ideas more quickly into the marketplace. ${ }^{48}$ Kenya has tried to establish such clusters through a project known as Konza city, but it is yet to be successfully rolled out.

\section{iv. Valuation of intangibles}

Valuation mechanisms help to determine the fair value of intangibles. Valuation is performed for a variety of purposes. Some of the circumstances that may trigger an intangible asset valuation component include as described.

First, financial reporting purposes: this is mostly in connection with accounting for business combinations, asset acquisitions and sales, and impairment analysis. An appropriate valuation needs to be carried out in order to determine the value that an entity reports. Second, tax reporting purposes: this will enable the actualisation of various tax objectives such as transfer pricing analyses, estate planning and reporting, and ad valorem taxation payment.

Third, litigation and dispute resolution: this may require valuation analysis in certain circumstances such as shareholder disputes, damage calculations and marital dissolutions (divorce); and fourth, statutory or legal events: this includes circumstances such as compulsory purchases/eminent domain proceedings, which require determination of appropriate value. ${ }^{49}$

Valuing intangible assets is hard because they have fuzzy boundaries. ${ }^{50}$ There are no universally recognised valuation techniques for intangibles and Kenya has no uniform framework. The International Valuation Standards Council, an independent standards organisation, has developed International Valuation Standards (IVS) 210 to guide in the valuation of intangible assets. ${ }^{51}$ These standards set forth requirements for the conduct of all valuation assignments. Kenya, through the Institution of Surveyors of Kenya, is a member of the

\footnotetext{
47 Marshall A, Principles of economics, 8 ed, Macmillan Publishers, London, 1920.

48 Locke G, Clustering for $21^{\text {st }}$ Century Prosperity, National Academics Conference, Washington DC, February 25, 2010.

49 International Valuation Standards Council, IVS 210:Intangible Assets, 2016 <https:/ /www.ivsc.org/ files/file/view/id/647>on 7 November 2018.

50 'The business of insuring intangible risks is still in its infancy', The Economist, 23 August 2018 $<$ https://www.economist.com/finance-and-economics/2018/08/23/the-business-of-insuringintangible-risks-is-still-in-its-infancy> on 7 November 2018.

51 International Valuation Standards Council, IVS 210: Intangible Assets, 2016.
} 
council.

In valuing an intangible asset, it is critical to understand specifically what needs to be valued. ${ }^{52}$ For example, customer data (names, addresses) typically has a very different value from customer contracts (those contracts in place on the valuation date), and customer relationships (the value of the on-going customer relationship including existing and future contracts). ${ }^{53}$ Therefore, what intangible needs are to be valued and how those intangible assets are defined may differ depending on the purpose of the valuation.

In the case of goodwill, this being any future economic benefit arising from a business, an interest in a business or from the use of a group of assets which has not been separately recognised in another asset, the value is the residual amount remaining after the values of all identifiable tangible, intangible and monetary assets, adjusted for actual or potential liabilities, have been deducted from the value of a business. ${ }^{54}$

It is typically represented as the excess of the price paid in a real or hypothetical acquisition of a company over the value of the company's other identified assets and liabilities. The amount is dependent on which other tangible and intangible assets are recognised, and its value can be different when calculated for different purposes. ${ }^{55}$

The IVS 210 outlines three approaches to valuing intangible assets. These include the cost approach, market approach, and income approach. ${ }^{56}$ The three methods can be briefly explained as follows:

First, the cost approach; intangible assets are valued on the basis of their 'cost to create' or costs that may be incurred to create a similar kind of asset, with equivalent commercial utility. For instance, for intellectual properties such as trademark, the costs will include naming, research and product design, packaging design, advertising and promotional expenditure. However, once created, the value of the intangible asset to its owner may be much higher than the cost to create it. ${ }^{57}$

52 OECD, Guidance on Transfer Pricing Aspects of Intangibles, 16 September 2016, <http://dx.doi. org/10.1787/9789264219212-en> on 14 November 2018.

53 International Valuation Standards Council, IVS 210: Intangible Assets, 2016.

54 Reilly R and Schweihs R, 'Intangible Assets', 31.

55 Power HouseCoopers, Valuation of intangibles, August 2007, < http://www.wipo.int/edocs/mdocs/ sme/en/wipo_smes_hyd_07/wipo_smes_hyd_07_www_91837.pdf> on 16 November 2018.

56 International Valuation Standards Council, IVS 210: Intangible Assets, 2016.

57 International Valuation Standards Council, IVS 210: Intangible Assets, 2016. 
Second, the market approach: This method, also known as 'sales comparison' approach, considers fair value of an intangible asset by making comparisons with actual sales of similar assets. The difficulty in applying this method is an intangible asset like brand cannot be sold separately from other business assets. Further, it is not easy to find examples of prices paid in outright sales for comparable assets. ${ }^{58}$

Third, the income approach estimation. In this method, the value of intangible assets is made by considering the net present value (NPV) of stream of future benefits accruing to the asset owner. The approach focuses on the future cash flow derived from a particular piece of an intangible. Assuming the intangible is a patent, to value it using this method, an income stream either from product sales or license of the patent, an estimate of the duration of the patent's useful life, an understanding of patent specific risk factors and incorporating those into the valuation, a discount rate, are required. ${ }^{59}$

The income approach method has three subsets. These are the discounted Cash Flow (DCF) method whose approach attempts to determine the value of the intangible by computing the present value of cash flows, attributable to that piece, over the useful life of the asset.

The other is relief from royalty method which looks at the amount of income that a company would be 'deprived' of, if it did not own the intangible in question but was required to rent it from a third-party instead. The royalty represents the rental charge, which would be paid to the licensor if this hypothetical arrangement were in place.

The last subset is the greenfield method where the value of the intangible is determined using cash flow projections that assume the only asset of the business at the valuation date is the subject intangible. All other tangible and intangible assets must be bought, built or rented. The greenfield method is often used to estimate the value of franchise-based intangible assets and broadcast spectrum. ${ }^{60}$

Upon valuation and recognition, intangible assets may be carried at a re-valued amount (based on fair value) less any subsequent amortisation and impairment losses only if fair value can be determined by reference to an active market. ${ }^{61}$ Inappropriate determination of value presents an opportunity for tax

58 Power House Coopers, Valuation of Intangibles, August 2007, <http://www.wipo.int/edocs/ mdocs/sme/en/wipo_smes_hyd_07/wipo_smes_hyd_07_www_91837.pdf> on 16 November 2018.

59 International Valuation Standards Council, IVS 210: Intangible Assets, 2016.

60 International Valuation Standards Council, IVS 210: Intangible Assets, 2016.

${ }_{61}$ IAS 38, Intangible Assets. 
leakages.

\section{v. Amortisation}

In valuation and accounting of an intangible asset, an important aspect to take into consideration is the economic life of the intangible. This period may be finite, limited by legal, technological, functional or economic factors. Other assets may have an indefinite life. ${ }^{62}$

Amortisation is the practice of reducing the value of assets to reflect their reduced worth over time. The term means the same as depreciation, though it tends to be used for the write-off of intangible assets. Amortising an asset effectively transfers its value, or the part that is being written off, from the balance sheet to the profit and loss account, where it reduces taxable income. ${ }^{63} \mathrm{An}$ intangible asset with a finite useful life is amortised, while the one with an indefinite useful life is not amortised. ${ }^{64}$

Legal, technological, functional and economic factors must be considered individually and together in making an assessment of the economic life. For example, a pharmaceutical technology protected by a patent may have a remaining legal life of five years before expiry of the patent, but a competitor drug with improved efficacy may be expected to reach the market in three years. This might cause the economic life of the patent to be assessed as only three years. ${ }^{65}$

Amortisation begins when the asset is available for use. The method used reflects the pattern in which the asset's future economic benefit is expected to be consumed by the entity. If that pattern cannot be determined reliably, the straight-line method is preferable over the range of useful lives, starting from the month of acquisition. ${ }^{66}$ For example, Safaricom Limited indicates its intangibles in the form of telecommunication license fees that are capitalised at cost and amortised over the period of the license using the straight-line method from commencement of the service of the network. ${ }^{67}$

In many tax jurisdictions, intangible assets can be amortised for tax

\footnotetext{
62 Investopedia, Amortisation of Intangibles, 16 July $2018<$ https://www.investopedia.com/terms/a/ amortization-of-intangibles.asp\#ixzz5OBUYduVZ> on 7 November 2018.

63 Financial Times, Definition of amortszation, at $<$ http://lexicon.ft.com/Term?term=amortisation $>$ on 16 November 2018.

64 Investopedia, Amortisation of Intangibles, 2018.

65 Investopedia, Amortisation of Intangibles, 2018.

${ }_{66}$ Petkova L, Tax Treatment of Intangible Assets, 2010.

67 Safaricom PLC, Annual Report 2018: Statement of Financial Position, 2018, 119.
} 
purposes, reducing a taxpayer's tax burden. In the United States for instance, a taxpayer is entitled to an amortisation deduction with respect to any amortisable intangible provided for under Section 197 of the Internal Revenue Code (IRC). ${ }^{68}$ The amount of such deduction is determined by amortising on adjusted basis (for purposes of determining gain). ${ }^{69}$ The classification of Section 197 of IRC in relation to intangibles is most often used in the valuation of a business for sale. ${ }^{70}$

To conclude, in creating a coherent policy for intangible assets, issues on acquisition, commercialisation, valuation and amortisation need to be considered. The methods used for each should be aimed at ensuring harmonised treatment of intangible assets in the financial books of entities across all industries.

\section{Review of the Regulatory Framework}

To determine the applicable legal framework, distinction is made between legally registered intangibles such as intellectual properties and non-registered intangibles which impose legal rights and are legally or contractually protected even if not registered. ${ }^{71}$ Legal rights associated with an intangible are found in registrations, contracts or other communications among the parties, which may establish the legal owner of the intangible and describe the roles, responsibilities, and rights associated with parties to the transaction involving the intangible. ${ }^{72}$

Intangibles in the nature of intellectual property rights (IP) are the most legally developed. The Constitution of Kenya, unlike many other constitutions around the world, has given anchorage to the intellectual property regime. It defines the term 'property' to include any vested or contingent right to, or interest in or arising from, among others, intellectual properties (emphasis author's own) and choses in action. ${ }^{73}$ It specifically requires the state to promote the intellectual property (IP) rights of the people of Kenya. ${ }^{74}$ Article 40(5)

68 Cornell.edu, Tax amortization $<$ https://www.law.cornell.edu/uscode/text/26/197 on November 152018.

69 Cornell.edu, Tax amortization.

70 <https://www.thebalancesmb.com/amortizing-intangible-assets-under-irs-section-197-398307 on 15 November 2018.

71 United Nations, Handbook on IPSAS Guidelines and Policy, <http://www.un.org/hr_handbook/ English/sourcedocuments_/tasktools_/guidelines_/ipsaspolicyfram/ipsaspolicyfram.pdf $>$ on 11 November 2018.

72 United Nations, Handbook on IPSAS Guidelines and Policy.

73 Article 260, Constitution of Kenya (2010).

74 Article 11 (2) (c), Constitution of Kenya (2010). 
obliges the government to, among other things, protect and enforce Kenyans' intellectual property rights. Further, Kenya has modern IP laws that protect copyrights, ${ }^{75}$ trademarks, ${ }^{76}$ patents, utility models, industrial designs, ${ }^{77}$ traditional knowledge, genetic resources and traditional cultural expressions, ${ }^{78}$ and plant breeder's rights. ${ }^{79}$

The institutional framework for protecting IP rights is composed of the Kenya Industrial Property Institute, the Kenya Copyright Board, Kenya Plant Health Inspectorate Services, and the Anti-Counterfeit Agency. Others include the Kenya National Innovation Agency and the National Research Fund that support the broader development of innovation landscape. ${ }^{80}$

The government's recognition that information is a valuable commodity in the information age is a step in the right direction. Intellectual property is central to converting that raw material, knowledge, information and ideas into tradable assets. ${ }^{81}$

The country has enacted the Movable Property Securities Assets Act 2017 to facilitate collateralisation of, among others, the intangibles, for secured borrowing and lending. The Consumer Protection Act, 2012 recognises internet and remote agreements which include digital based transactions. Lastly, companies allowing payments in crypto currencies, such as Bitpesa, are increasingly gaining foothold in Kenya. ${ }^{82}$ An overall assessment is that there are positive strides in developing legal framework to support intangibles in the country.

For accounting and taxation purposes in relation to intangibles, the regulatory framework includes the Accountants Act, ${ }^{83}$ the Income Tax Act, ${ }^{84}$ the Companies Act, ${ }^{85}$ the International Financial Reporting Standards (IFRS), ${ }^{86}$

\footnotetext{
75 Copyright Act (Act No. 12 of 2001).

76 Trademark Act (Act No. 51 of 1955).

77 Industrial Property Act (Act No. 3 of 2001).

78 Protection of Traditional Knowledge and Cultural Expression Act (Act No. 33 of 2016).

79 Seeds and Plant Varieties Act (Act No. 1 of 1972).

80 WIPO Magazine, Strengthening Kenya's IP Landscape, 2016 <http://www.wipo.int/wipo_ magazine/en/2016/04/article_0007.html on November 12, 2018.

81 WIPO Magazine, Strengthening Kenya's IP Landscape, 2016.

82 At the time of writing this paper, Kenya had not formulated a legal framework to regulate virtual commodities in the country.

83 Accountants Act (Act No. 15 of 2008).

84 Income Tax Act (Act No. 16 of 1973).

85 Companies Act (Act No. 17 of 2015).

86 These standards are the successors of the International Accounting Standards, some of which are still in use.
} 
and International Public Sector Accounting Standards (IPSAS). ${ }^{87}$ The global accounting standard setting bodies are the International Accounting Standards Board (IASB) and the Financial Accounting Standards Board (FASB).

The principles of international law such as academic scholarships, directives of international bodies such as the OECD, EU and UN Tax Committee, if deemed to constitute part of customary international law, consequently, do form part of the Law of Kenya. ${ }^{88}$ Under the Schedule Four to the Kenyan Constitution, the function of regulating IP is designated to the national government, hence only the national government may impose taxes on them.

The Companies Act defines the prescribed financial accounting standards applicable in Kenya as statements to standard accounting practice issued by a professional body or bodies in accounting and finance. The Institute of Certified Public Accountants and Public Sector accounting standards board are regulators of the accounting profession in private and public sector respectively in the country and have allowed the usage of IFRS and IPSAS as the accounting guidelines in the country. As this study noted in previous part, the accounting treatment of intangible assets is outlined in the International Accounting Standard (IAS) 38. Other applicable standards include IFRS 3 which deals on business combinations and IAS 36 which deals with 'impairment of assets'.

In practice, only when an accounting aspect of an intangible is addressed, is it recognised for tax purposes in accordance with respective tax laws. ${ }^{89}$ The tax treatment depends on who owns the intangible asset, who makes the payment, and the nature of activity the assets are employed for. The specific taxes payable depend on how individuals who create or own the intangibles are compensated. On the international taxation aspects, the Organisation for Economic Cooperation and Development (the OECD) has set out principles aiming at deterring international tax avoidance using the intangible assets ${ }^{90}$ addressed later in this study.

Despite the huge constitutional prominence given to intellectual properties and other intangibles, Kenya has no coherent policy framework to guide their taxation. There are no specifically tailored tax incentives extended to the inventors

\footnotetext{
These are the accounting standards for public sector in regard to non-commercial entities Article 2(5), Constitution of Kenya (2010).

Petkova L, Tax Treatment of Intangible Assets, 2007.

Laskar M, 'Levy of Income Tax on Intellectual Property', Social Science Research Network, 2014, $3<$ https://ssrn.com/abstract $=2400900>$ on 6 November 2018.
} 
and innovators. To that extent, the government is not able to efficiently tap them to maximise revenue collection.

One of the biggest regulatory dilemmas in dealing with intangible assets is the ongoing practice by Multinational entities (MNEs) to exploit them for tax avoidance. Specifically, the use of intangible assets for aggressive tax planning through transfer pricing has been rampant. ${ }^{91}$ Transfer pricing refers to pricing arrangements set by MNEs and their affiliates in respect of transactions such as the sale of goods, provision of services, transfer of intangible assets, lending or borrowing of money and other transactions that affect profit or loss of the entities. ${ }^{92}$ This enables a country in which a designated group member is resident to tax the profits.

One of the mechanisms commonly used by MNEs is creating complex corporate structures with intermediate entities scattered in various low tax jurisdictions. The practice has been rampant with US tech firms but is increasingly being adopted in developing countries. Apple Inc. case is one of the landmark transfer pricing cases in relation to intangibles and has contributed to shaping international tax policy on intangibles. To appreciate this aspect, a brief elaboration of the Apple case is necessary.

Apple is one of the largest companies in the world by market capitalisation. ${ }^{93}$ The company was investigated by the EU for structuring its transfer pricing policy on intangibles to avoid taxes. ${ }^{94}$ The facts were that in 1980, Apple Inc., a U.S. tax resident company, established three wholly owned subsidiaries in Ireland: Apple Operations International (AOI), Apple Operations Europe (AOE), and Apple Sales International (ASI). AOI, a holding company, owns most of Apple's offshore entities and operated without a physical presence and without any employee. AOE, with a physical presence in Ireland, was in charge of manufacturing a specialised line of computers and of providing intragroup services, such as payroll services, centralised purchasing and a customer call centre. ASI, with a physical presence in Ireland, engaged in unrelated contract

91 Ross A, 'Taxation and Pricing of Intangibles' Singapore Management University School of Accountancy Research Paper Number 2016-S-44, 22. <https://ssrn.com/abstract=2722836> on 12 November 2018.

92 Ross A, Taxation and Pricing of Intangibles, 22.

93 Salinas S, 'Apple hits \$1 trillion market cap' Consumer News and Business Channel, 2 August 2018, <https://www.cnbc.com/2018/08/02/apple-hits-1-trillion-in-market-value.html> on 14 November 2018

94 Simontacchi S, ' Rethinking international tax law; the Apple case' University of Leiden, 4 May 2017 --<https://www.coursera.org/lecture/international-taxation/apple-case-v8x83> on 6 August 2018. 
manufacturers to assemble products that were sold to distribution subsidiaries in Europe and Asia and, in most cases, products did not transit through Ireland. ${ }^{95}$

Apple Inc. entered into a cost-sharing agreement with AOI and ASI. ${ }^{96}$ Under the cost sharing agreement, the two subsidiaries acquired economic rights to exploit Apple's IP outside the United States. Apple was able to manipulate the different rules between Ireland (place of effective management) and the U.S. (place of incorporation) for establishing the residence of a company in their territory, resulting in no residence and double non-taxation. The company licensed IP rights and rights to use the company's brand to global subsidiaries, receiving remuneration (royalties) and, consequently, profit back in Ireland. ${ }^{97}$ The EU's state aid investigation found out these agreements lowered the effective tax rate of these two companies in Ireland. For instance, ASI paid only 13 million US Dollars of taxes in 2011. If Apple had not entered into the cost-sharing agreement, its 2011 US income before tax would have increased by approximately 22 billion US Dollars. ${ }^{98}$ The EU Commission concluded that these agreements constituted a form of state aid and ordered Apple Inc. to pay the taxes avoided. Both the company and Ireland have appealed the ruling. ${ }^{99}$

In Kenya, there are reported cases of tax avoidance by manipulation of transfer pricing on intangible assets. Wananchi Group, internet provider firm, is embroiled in a court battle with the Kenya Revenue Authority (KRA) for alleged tax avoidance through jurisdiction shopping for IP in an intricate corporate structure reproduced below. ${ }^{100}$

95 Simontacchi S, ' Rethinking international tax law; the Apple case’ University of Leiden, 4 May 2017 $--<$ https://www.coursera.org/lecture/international-taxation/apple-case-v8x83> on 6 August 2018.

96 A cost sharing agreement is a framework agreed between enterprises to share the costs, risks and benefits of developing intangible assets.

97 Ting A, iTax-Apple's international tax structure and the double non-taxation issue' British Tax Review, 2014, 47 --<www.sweetandmaxwell.co.uk/catalogue/eDownloadDoc.aspx?filename=33> on 14 August 2018.

98 Simontacchi S, ' Rethinking international tax law; the Apple case’ University of Leiden, 4 May 2017 --<https://www.coursera.org/lecture/international-taxation/apple-case-v8x83> on 6 August 2018.

99 Simontacchi S, ' Rethinking international tax law; the Apple case' University of Leiden, 4 May 2017 --<https://www.coursera.org/lecture/international-taxation/apple-case-v8x83> on 6 August 2018.

100 Michira M, 'Here's why KRA is demanding Sh3.4 billion from Zuku owners' The Standard, 11 November 216 -- <https://www.standardmedia.co.ke/business/article/2000223004/here-s-whykra-is-demanding-sh3-4-billion-from-zuku-owners> on November 142018. 
Figure 2: Graphical representation of Wananchi group structure:

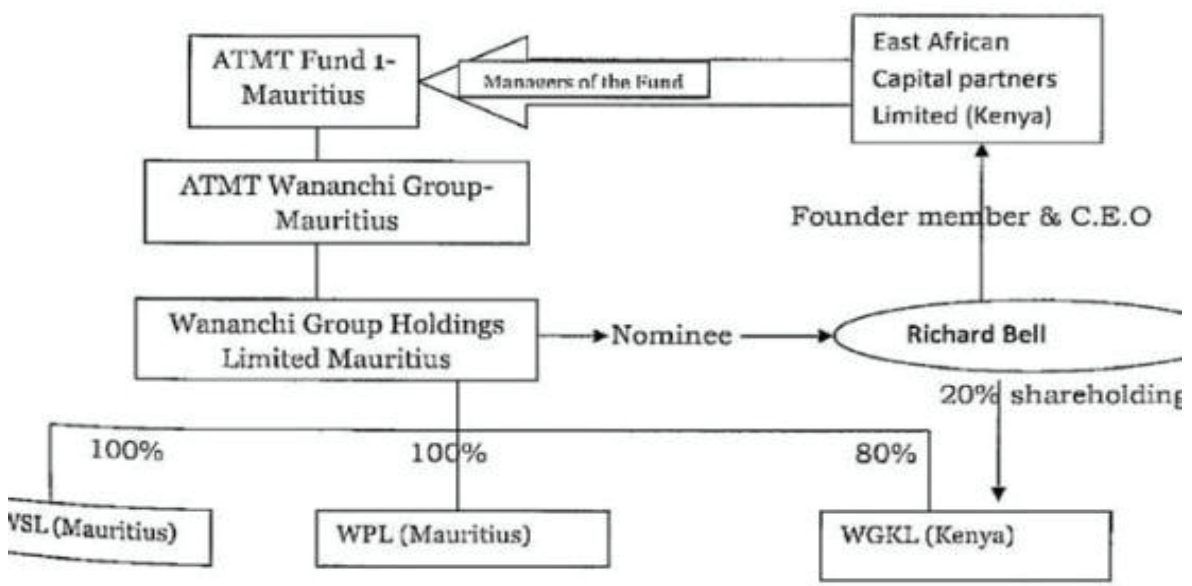

The figure illustrates a structure of Wananchi Group. To expound, Richard Bell is a major shareholder in Wananchi Group Holdings Limited (Mauritius), which fully owns Wananchi Satellite (WSL) and Wananchi Programming (WPL) and has an $80 \%$ stake in Wananchi Group Kenya Limited. Wananchi Group Holdings is wholly owned by ATMT Wananchi Group (Mauritius), which is also wholly owned by ATMT Fund 1 (Mauritius). East African Capital Partners Limited (Kenya), owned by Richard Bell, manages ATMT Fund 1 (Mauritius). In essence, ownership by Bell in the Kenyan subsidiary is both direct and indirect through four layers: EACP, ATMT Fund 1, ATMT Wananchi Group Mauritius and Wananchi Group Holdings. ${ }^{101}$ When KRA investigated the structure, they appointed Richard Bell as the tax representative of the offshore companies, making him answerable on the suspected tax avoidance, the action he appealed. ${ }^{102}$ Aggrieved by these developments, the company is reported to be planning to exit the Kenyan market. ${ }^{103}$

101 Michira M, 'Here's why KRA is demanding Ksh 3.4 billion from Zuku owners' The Standard, 11 November 2016 <https://www.standardmedia.co.ke/business/article/2000223004/here-s-whykra-is-demanding-sh3-4-billion-from-zuku-owners> on November 142018.

102 Fayo G, 'Zuku founder suffers blow in Ksh3bn tax row' Business Daily Africa, 13 September 2018.

103 Amadala V, 'Zuku owners to exit as rivals control data market' October 16, 2018 < https://www.thestar.co.ke/news/2018/10/16/zuku-owners-to-exit-as-rivals-control-data-market_c1835227> on November 142018. 
Given the growing importance of intangible assets as a source of economic growth and tax revenue, as well as the fact that their non-physical nature makes it easier for taxpayers to engage in tax strategies such as income-shifting or transfer pricing, tax authorities. As Apple Inc. and Wananchi cases illustrate, use of intangible assets is a popular conduit for base erosion and profit shifting, a risk the regulatory framework is yet to sufficiently address. In the next part, this paper will discuss possible recommendations on how to address the issue.

\section{Tax Treatment of Intangible Assets}

Tax treatment is the manner in which accounting gains (or losses) are charged to tax in year of income. As previously noted, financial accounts are drawn in accordance with accounting standards, but thereafter adjusted for purposes of tax computations. ${ }^{104}$ This part explores tax treatment on intangible assets from perspectives of various tax heads and proposals contained in the Kenyan draft Income Tax Bill 2018. ${ }^{105}$

\section{i. $\quad$ The Income Tax}

Like other assets, intangibles generate income subject to income tax. The governing statute is the Income Tax Act (ITA). ${ }^{106}$ The ITA has three key provisions that bring to charge tax from incomes accruing from intangible assets.

Section 3 (2) (a) (iii) brings to charge gains or profits from rights granted for the use of property. Section 10 provides that where a resident or person has created a permanent establishment that makes payment in respect of 'a royalty or natural resource income', they are liable to tax. Lastly, Section 35 provides for withholding tax on payment of royalties. Royalty payments are the main consideration emanating from intangible assets that attract taxes. Royalty income is classified as a specific source of income and therefore computed separately from other incomes. ${ }^{107}$

\footnotetext{
104 The books are adjusted for tax purposes because there are numerous expenses allowed for accounting purposes but disallowed for tax purposes. Kenya is currently reforming the Income Tax Rules. One of the suggestions is to adopt the United Kingdom framework as described here http:/ / www.buzzacott.co.uk/getattachment/cf0fa620-6bb6-429c-8061-67228d94b57c/the-uk-taxationof-intellectual-property-(ip)

105 The proposed bill was yet to be tabled in parliament at the time of writing this paper.

106 Income Tax Act (Act No. 16 of 1973).

107 Section 15(7), Income Tax Act (Act No. 16 of 1973).
} 
Section 2 of the ITA defines royalty to mean a

'payment made as a consideration for the use of or the right to use any copyright of a literary, artistic or scientific work; or any cinematograph film, including film or tape for radio or television broadcasting; or any patent, trade mark, design or model, plan, formula or process; or any industrial, commercial or scientific equipment.'

A royalty income will accrue from either a lease or licence to use an intangible. The taxes on royalty payments are deducted at source through the withholding tax system. The current rate is $5 \%$ for payments to residents and $20 \%$ for payments to a non-resident, subject to any rate provided for in a double taxation agreement (DTA) available between Kenya and the country of a nonresident counterpart.

The disposal of an intangible may be classified as a capital asset in nature, hence attracting capital gains tax, which is levied on adjusted gains at a rate of $5 \%$. However, it has been noted that KRA has not been rigorous in ensuring the actualisation of capital gains on transfer of intangibles since the re-introduction of capital gains tax in Kenya in January 2015. ${ }^{108}$ This is a revenue gap that the revenue agency could capitalise on.

The ITA allows expenses that have been wholly and exclusively incurred in production of income to be allowed against income for tax purposes. Section 15 of the ITA provides for allowable (deductible) expenses and Section 16 goes further to list certain expenses that, though allowed for accounting purposes, are disallowed (non-deductible) in computing taxable income.

The only intangible assets allowed by the ITA for capital expenditure is the software at a rate of $20 \%$. Paragraph $31 \mathrm{~B}$ of the Second Schedule states that:

'Subject to this Schedule, where a person incurs capital expenditure on the purchase or acquisition of the right to the use of a computer software, there shall be deducted, in computing his gains or profits for the year of income in which the software is first used and for subsequent years of income, an amount equal to one-fifth of that expenditure'. ${ }^{109}$

The Paragraph 31B to the Second Schedule was introduced into the ITA in the year 2009. Before then, practice had developed where software depreciation was treated by industry as machinery and subjected for wear and tear deduction at

108 Gatuyu J, 'What is your gain? Intricacies of capital gains tax on property transactions in Kenya' 14(1), Law Society of Kenya Journal, 2018, 66 see generally 66-87.

109 The provision was introduced into the ITA by the Finance Act, 2009 and become effective from Jan, 2010. 
the rate of $12.5 \%$. However, this became contested, in the case of CFC Stanbic Bank Ltd $v$ Kenya Revenue Authority $\mathcal{E}$ another where the court accurately noted that ITA did not have any specific provision allowing capital deductions on computer software. ${ }^{110}$

Nevertheless, the allowable and disallowable expenses under the ITA have made little reference to intangible assets. For example, even though capital allowances at provided rate is a deductible expense on commercial buildings, there is no express provision for allowing deductibility of research and development for creating intangible assets.

Lack of clarity in tax law in treating intangibles was witnessed in Commissioner Of Income Tax v Kencell Communications Limited (Now Airtel Kenya Limited). ${ }^{111}$ In this case, Airtel had deducted the payment of its licence purchase as revenue expenditure, which in effect lowered its tax burden. The KRA reassessed its books and held that license fees should be treated as capital expenditure. This triggered a protracted tax arrears demand in court. The High Court agreed with KRA and ruled that purchase of an operation license is capital and not revenue expenditure. In the ruling, the court further noted that Kenyan law does not offer clarity on whether license fees should be capitalised or expensed.

It is notable that the ITA grants huge tax incentives to investors to encourage direct investments and job creation in special zones such as Export Processing Zones and Special Economic Zones. Similar tax incentives ought to be extended to clusters created to commercialise intangible assets.

The taxation of intangibles, especially intellectual properties, has received mixed reactions from Kenyan courts. In Barclays Bank of Kenya $v$ Kenya Revenue Authority, KRA demanded tax payments on fees remitted to Visa, Mastercard and American Express for electronic money transfer services after classifying such payments as management fees. The court ruled that classifying royalty fees as withholding tax is vague and such a basis could not be used to demand levies from the bank. ${ }^{112}$

In Vivo Energy Kenya Limited v Kenya Revenue Authority KRA made a conclusion to the effect that Vivo Energy Kenya Limited's non-exclusive and non-transmissible license to use 'Shell' trademarks was a sale of a property that

\footnotetext{
(2014) eKLR.

(2016) eKLR.
}

12 (2013) eKLR. 
gave rise to royalty within the meaning of Section 2 of the ITA, hence chargeable to tax. ${ }^{113}$ Vivo Energy argued that it had not acquired the trademark but rather was only given non-exclusive and non-transmissible rights to use 'Shell' trade marks in Kenya. The court concluded that the payment by Vivo for use of brand 'Shell' to facilitate brand development was not a gain derived from the sale of a property giving rise to a royalty under the ITA and KRA should not have accessed tax on it.

In Republic v Kenya Revenue Authority Ex-parte Bata Shoe Company (Kenya) Limited ${ }^{114}$ the court held that distribution royalties are not subject to customs duty as they are not royalties related to the goods being valued that the buyer must pay, either directly or indirectly. These court cases illustrate the need to provide legislative clarity on income taxation of intangible assets.

Additionally, the ITA does not have provisions to guide on the transfer pricing on intangibles. There are Transfer Pricing Regulations made under the ITA but these have no guidance on intangibles. ${ }^{115}$ The proposed Income Tax Bill 2018 has made attempts to address the issue.

\section{ii. Customs Duties}

The customs duties in the East African Community are governed mainly by the East African Customs Management Act and various instruments by the World Customs Organisation and the World Trade Organisation (WTO). In 1998, the WTO imposed a moratorium on charging customs duty for intangible products, consequently suspending the intangibles tariff. ${ }^{116}$ Under this moratorium, developing countries, such as Kenya, are not allowed to impose import duties on intangible goods. This position is, however, expected to be reviewed in December 2018 WTO Ministerial Conference. ${ }^{117}$

With the growing e-commerce, and booming digital assets such as e-books and music, imposition of import duties on intangible goods has the potential to broaden the revenue base. The developing nations ought to lobby for the

\footnotetext{
(2016) eKLR.

114 (2015) eKLR.

115 The Regulations were enacted after the government lost a transfer pricing case in Unilever Limited $\checkmark$ Commissioner of Domestic Taxes.

116 The WTO moratorium has been effective since May 20 in 1998 in the Second Ministerial Conference in Geneva.

117 Yuafanda H, 'Welcoming import duties on intangible goods' Academia.edu, January 10, 2018 $<$ http://www.thejakartapost.com/academia/2018/01/10/welcoming-import-duties-on-intangiblegoods.html> on November 142018.
} 
lifting of this moratorium and the reinstatement of the intangibles tariff. Some countries such as Indonesia have indicated they will start levying import duties in intangibles upon the expiry of the WTO moratorium. ${ }^{118}$

On valuation of intangibles for customs, WTO Agreement on Customs Valuation provides that any fees paid as royalties or license fee needs to be added to the customs value. However, the right to reproduce the imported goods in the country is excluded for the purpose of custom valuation.

\section{iii. Excise duty}

The Kenyan Excise Duty Act 2015 does not classify generation of intangibles as creating excisable goods or as a manufacture. Thus, no excise duty rate is provided for under the First Schedule to this Act.

\section{iv. Stamp Duty}

The Stamp Duty Act provides for a duty payable on instrument of 'conveyance' of property situated under any 'municipality' under Paragraph 12 to the Schedule of the Act. This is an old statute enacted before the regime of intangibles gained prominence, and may not have foreseen the rise of the intangible economy. The Act needs amendments to factor in intangible assets and ensure a stamp duty is levied in relation to instrument related to transfer of intangible assets. In the current practice, stamp duty is majorly imposed on instruments of transfer of specified tangibles such as land.

\section{v. Value added Tax}

The Kenyan Value Added Tax (VAT) Act 2013 defines 'supply of services' to mean 'anything done that is not a supply of goods or money, including: performance of services for another person; grant, assignment or surrender of any right; making available of any facility or advantage; or the toleration of any situation or the refraining from the doing of any act ${ }^{119}$.

By virtue of the wide definition of expression 'supply of service', any grant of any rights in respect of an intangible asset, their transfer or assignment, is

\footnotetext{
118 Nasution D, 'Import duty to be slapped on intangible goods in 2018: Darmin' Antara News, 11th December $2017<$ https://en.antaranews.com/news/113800/import-duty-to-be-slapped-onintangible-goods-in-2018-darmin> on November 142018.

119 Section 2, Value Added Tax Act (Act No. 35 of 2013).
} 
regarded as a supply of services for VAT purposes. Consequently, VAT at the applicable rate is charged by a VAT registered person on royalties and similar licence payments. ${ }^{120}$

\section{vi. The draft Income Tax Bill, 2018}

The National Treasury of Kenya has initiated the process of reviewing the income tax regime in the country. In mid-2018, a draft Income Tax Bill, 2018 was released for public consultations. A main weakness with the draft is that the basis for taxation was unchanged. ${ }^{121}$ However, it is comparatively progressive on aspects of transfer pricing on intangibles.

Clause 26(5) (5) of the draft bill provides that in computing the gains or profits of associated persons, the provisions of the Eighth Schedule shall apply. Paragraph 5 of the Eighth Schedule provides one of the transactions subject to transfer pricing adjustment is 'the purchase, sale, transfer, lease or use of tangible or intangible property'. This demands that transfer of intangible assets has to be carried out at arm's length. In determining the arm's length price, paragraph 6 provides any of the following methods may be applied:

Comparable Uncontrolled Price (CUP): This method compares the price charged for a property or service transferred in a controlled transaction to the price charged for a comparable property or service transferred in a comparable uncontrolled transaction in comparable circumstances.

Resale Price Method (RPM): This is used to determine the price to be paid by a reseller for a product purchased from an associated enterprise and resold to an independent enterprise. The purchase price is set so that the margin earned by reseller is sufficient to allow it to cover its selling and operating expenses and make an appropriate profit.

Cost plus Method: This is used to determine an appropriate price to be charged by a supplier of property or services to a related purchaser. The price is determined by adding to costs the supplier incurred an appropriate gross margin so that the supplier will make an appropriate profit in light of market conditions and functions performed.

120 Fairpo A, 'VAT and intangibles: VAT in a blockchain world' Tax Journal, 2018, <https://www. taxjournal.com/articles/vat-and-intangibles-vat-blockchain-world-14022018> on November 14 2018.

121 Price Waterhouse Coopers (Kenya), 'Tax alert on the draft income tax bill' 2 May 2018- < https:// www.pwc.com/ke/en/assets/pdf/alert-income-tax-bill-2018.pdf> on November 152018. 
Transactional Net Margin Method (TNMM): The method seeks to compare the level of profits that would have resulted from controlled transactions with the return realised by the comparable independent enterprise. It compares the net profit margin realised from the controlled transactions with the net profit margin realized from uncontrolled transactions.

Profit-split Method: This takes the combined profits earned by two related parties from one or a series of transactions and then divides the profits using a defined basis that is aimed at replicating the division of profits that would have been anticipated in an agreement made at arm's length. Arm's length pricing is therefore derived from both parties by working back from profit to price

Analysing these methods in relation to intangible assets, the CUP method appears to be the most reliable in regard to application of the arm's length principle. It relies on comparability, thus setting the closest price possible to an uncontrolled transaction.

The RPM is one-sided and relies on the price charged to an independent party to whom the asset is resold after the controlled transaction has taken place. ${ }^{122}$ The comparability issue arises only through the functional analysis of the transactions, which results in the gross margin. ${ }^{123}$ The cost-plus method is also one-sided, and takes as a starting point the costs realised by the supplier in a controlled transaction and then adds the appropriate profit mark-up. The Profit Split Method (PSM) is a two-sided method, as profits and losses are split between the parties involved in a transaction. ${ }^{124}$ Therefore, the KRA should, as far as practicable, encourage the application of the CUP method in determining the transfer price of intangibles as it is less subjective.

Lastly, paragraph 13 of the Eight Schedule to the draft bill specifically provides for transactions involving intangible property. It states that determination of arm's length conditions for controlled transactions involving the exploitation of an intangible must take into account 'the contractual arrangements in respect of the development, enhancement, maintenance, protection and exploitation of the asset'.

These are what are known as DEMPE functions first proposed by the OECD Base Erosion and Profit Shifting (BEPS) action plan 8. The aim is to

OECD Transfer Pricing Guidelines 2016, 'resale price margin’2.21.

123 Monsenego J, Introduction to transfer pricing, 3rd ed, Studentlitteratur, Lund, 2013.

124 Monsenego J, Introduction to transfer pricing. 
encourage businesses to review their value chains to ensure that intangible assets are correctly identified, including existing contracts and arrangements for the development, enhancement, maintenance, protection and exploitation of intangibles.

Ostensibly, transfer pricing on intangibles has emerged as the main risk in relation to intangible assets, and it is encouraging that this draft bill has given the issue deserving prominence.

\section{vii. OECD BEPS Action 8}

The OECD has recommended the BEPS Action Plans ${ }^{125}$ aiming to combat base erosion and profit shifting through coordination between the countries involved. The aim of these OECD recommendations is to develop 'uniform' rules and reform international tax law. Transfer pricing on intangibles is one out of four transfer pricing areas of the BEPS project. ${ }^{126}$ The High Court in the case Unilever Limited $v$ Commissioner of Domestic Taxes ${ }^{127}$ held that the OECD principles are applicable in Kenya where there are no equivalents.

The BEPS Action 8 contains standards for the transfer pricing of intangibles. These include guidance on the definition of intangibles, the identification and characterisation of transactions relating to intangibles, and on the application of the arm's length principle. ${ }^{128}$

Action 8 deals with the attribution of profits associated with the exploitation of intangibles. It proposes that although the legal rights are the starting point of the analysis, the relevant remuneration must be attributed to the entity. ${ }^{129}$

125 In a summary, the OECD BEPS Action points are as follows: Action 1: Addressing the Tax Challenges of the Digital Economy, Action 2: Neutralising the Effects of Hybrid Mismatch Arrangements, Action 3: Designing Effective Controlled Foreign Company Rules, Action 4: Limiting Base Erosion Involving Interest Deductions and Other Financial Payments Action 5: Countering Harmful Tax Practices More Effectively, Taking into Account Transparency and Substance, Action 6: Preventing the Granting of Treaty Benefits in Inappropriate Circumstances, Action 7: Preventing the Artificial Avoidance of Permanent Establishment Status, Actions 8-10: Aligning Transfer Pricing Outcomes with Value Creation, Action 11: Measuring and Monitoring BEPS, Action 12: Mandatory Disclosure Rules Action 13: Guidance on Transfer Pricing Documentation and Country-by-Country Reporting, Action 14: Making Dispute Resolution Mechanisms More Effective, Action 15: Developing a Multilateral Instrument to Modify Bilateral Tax Treaties.

126 OECD, Guidance on Transfer Pricing Aspects of Intangibles, 2016.

127 (2006) eKLR.

128 OECD, Guidance on Transfer Pricing Aspects of Intangibles, 2016.

129 Beale L, '\#Wow: Reforming Intellectual Property Taxation (or Maybe IP Law)' Wayne State University Law, Wayne State University Law School Research Paper Number 15, 2016, $1255-$ < https://ssrn.com/abstract=2802303> on 14 May 2018. 
Therefore, remuneration must be attributed to the party (or parties) generating value and controlling risks and mere ownership of intangibles without the performance of any of these functions leads to a low remuneration. ${ }^{130}$

To ascertain arm's length principle, a comparable transaction must occur between independent parties. The definition of what constitutes arm's length has been provided under Article 9 of the OECD Model Tax Convention which states that:

'when conditions are made or imposed between the two enterprises in their commercial or financial relations which differ from those which would be made between independent enterprises, then any profits which would, but for those conditions, have accrued to one of the enterprises, but, by reason of those conditions, have not so accrued, may be included in the profits of that enterprise and taxed accordingly'. ${ }^{131}$

Often, multinationals use cost-sharing agreements in order to develop and enhance their intangibles and locate them to jurisdictions, in which none of the core intangibles activities are carried out. ${ }^{132}$ On this, BEPS Action 8 provides that the use or transfer of intangibles should begin with an identification of the commercial and financial relations entered into by the associated enterprises and the economically relevant characteristics attached to those relations. ${ }^{133}$

The key aspect is to ascertain who performs and controls all of the important functions related to the intangibles, provides all assets, including funding, necessary to the development and exploitation of the intangibles, and bears and controls all of the risks related to the development and exploitation of the intangibles. ${ }^{134}$

In 2017, the OECD released a revised guidance on transfer pricing on intangibles which mainly focuses on DEMPE functions on intangibles. The guidance will most likely result in significant changes on how MNEs implement the arm's length principle. ${ }^{135}$

DEMPE functions are designed to ensure that allocation of the returns from the exploitation of intangibles, and also allocation of costs related to intangibles, is performed by compensating MNE group entities for functions

\footnotetext{
Petkova L, Tax Treatment of Intangible Assets, 2007.

Article 9, OECD Model Tax Convention.

OECD, Guidance on Transfer Pricing Aspects of Intangibles, 2016.

OECD, Guidance on Transfer Pricing Aspects of Intangibles, 2016.

OECD, Guidance on Transfer Pricing Aspects of Intangibles, 2016.

135 DEMPE was first introduced in the final Actions 8-10 report of the Transfer Pricing Aspects of Intangibles 'Aligning Transfer Pricing Outcomes with Value Creation', released on October 5th 2015.
} 
performed, assets used, and risks assumed in the development, enhancement, maintenance, protection and exploitation of intangibles. ${ }^{136}$

The report states that 'a determination that a particular group member is the legal owner of intangibles does not, in and of itself, necessarily imply that the legal owner is entitled to any income generated by the business after compensating other members of the MNE group for their contributions in the form of functions performed, assets used, and risks assumed. ${ }^{137}$

DEMPE is designed to help both taxpayers and tax authorities achieve an accurate assessment of transactions to help with the determination of appropriate transfer pricing. ${ }^{138}$ Before the DEMPE concept was introduced, the legal owner of an intangible was entitled to essentially all the returns generated by that particular intangible. ${ }^{139}$

This meant that, in practice, the owner of a brand could set up their company, for example, in Kenya, but also register their trademark in a low-tax environment such as Mauritius, so that they could charge royalties to the Kenya business for any income related to the IP registered in the low-tax environment. In such case, the IP owner would be entitled to the income effectively generated by the Kenyan entity. ${ }^{140}$

However, any income that is generated as a result of that IP is owned by all the parties that perform the DEMPE functions. Rather than the IP owner receiving the full amount of the returns generated by the intangible, these instead have to be divided between the relevant parties, in line with each entity's contribution to the value of the intangible. In this example, if there were entities in Mauritius that carried out DEMPE functions, then they would be entitled to a proportional share of the income generated by the intangible in question. ${ }^{141}$

If no DEMPE functions resulted from the Mauritius activities, then under the new approach the Kenya tax authorities would likely disallow the Mauritius royalty deductions from the taxable Kenyan profits, especially if these functions were performed by the Kenyan entity. In such a case, the legal ownership of

\footnotetext{
136 Rudzika K, DEMPE Functions, Royalty Range, 2018 , < https://www.royaltyrange.com/home/ royalty-rate-database/DEMPE> on November 142018

137 Rudzika K, DEMPE Functions, Royalty Range, 2018.

138 OECD, Aligning Transfer Pricing Outcomes with Value Creation, 2015 <http://www.oecd. $\mathrm{org} / \mathrm{ctp} /$ aligning-transfer-pricing-outcomes-with-value-creation-actions-8-10-2015-final-reports9789264241244-en.htm on November 142018.

139 Rudzika K, DEMPE Functions, Royalty Range, 2018.

140 Rudzika K, DEMPE Functions, Royalty Range, 2018.

141 Rudzika K, DEMPE Functions, Royalty Range, 2018.
} 
intangibles, by itself, does not confer the right to retain returns derived by the MNE group from exploiting the intangible asset. ${ }^{142}$ The proposal by the draft Income Tax Bill to incorporate DEMPE functions into the Kenyan tax regime is progressive.

\section{Conclusion and Recommendations}

It can safely be concluded that investments in intangible capital are surpassing the tangible capital. Kenya is a fairly intellectually rich country, yet most Kenyans fail to recognise the value of their intangible assets and hence do not monetise them. Even with the clearly identifiable intangibles such as copyrights and trademarks, the rate of their registrations with relevant bodies is low. The starting point is for the government to create awareness on identifying and protecting their valuable intangible assets.

The interdependency between intangibles and taxation is a complex affair. Physical limitations, which have long defined traditional taxation concepts, no longer apply. Traditional methods of taxation, developed in a different technological era, have to be adapted to take into account the changing nature of undertaking business in a virtually borderless world.

Kenya, as well as other emerging economies, needs to tap into the new models of assets presented by the rise of the knowledge economy, to get more revenue for their governments. This could be achieved by creating a supportive policy and legal framework. The loopholes multinationals exploit by using intangibles to avoid taxes, as illustrated by Apple Inc. and Wananchi group cases, need to be sealed. Further, the industry needs incentives to grow. For instance, expenses of research and development costs in creation of intangibles could be treated as tax allowable.

Typically, developing countries are more vulnerable to corporate tax base erosion by MNEs than developed countries, which are often partly responsible for this erosion, and thus should be equally aggressive in fighting BEPS. Transfer pricing, source of income and determination of legal and economic ownership of group intangible assets represent the tax problem with which authorities around the world are now wrestling. On intangible assets, the OECD BEPS Action 8 is fairly comprehensive, especially on the aspect of DEMPE functions, and developing coun-

142 Rudzika K, DEMPE Functions, Royalty Range, 2018. 
tries should be encouraged to domesticate its principles in their domestic tax laws.

The ITA should extend some of the tax incentives granted on tangible economy to the intangible economy. A case is made for granting tax relief on capital expenditure incurred by entities on the acquisition of intangible assets. Such would enhance Kenya's appeal as a location for the development and exploitation of intangibles. It would also encourage more companies to develop and exploit intangible assets and expand portfolio of overseas investors. In the same breath, due to increased interconnectedness of states and mobility of intangible assets, countries such as Kenya ought to expand their treaty networks.

There is also a need to reform the accounting rules on identification, recognition and measurement of intangibles. As illustrated under Part II of this paper, the accounting rules only provide for recognition and impairment of goodwill. Similar guidelines ought to be extended to the spectrum of other intangibles. Uniform guidelines for calculating depreciation or amortisation of intangibles and to guide on valuation need to be adopted.

To facilitate commercialisation of intangibles, there is need for the development of innovation clusters such as the U.S. innovation zones of Silicon Valley and Research Triangle Park. As Michael Porter observed, to secure competitive advantage against other regions, communities must be able to fully exploit knowledge, relationships, and motivation that distant rivals cannot match. ${ }^{143}$ Such sentiment supports creation of innovations centres such as the proposed Konza technology city.

Such reforms will boost the continued development of the intangible assets industry, and further create a revenue stream which government would tap by way of taxation. These proposals are not only relevant to Kenya but to the developing countries as they face similar predicaments as heralded by the rise of the knowledge economy.

143 Porter M, 'Clusters and the new economics of competition' 76(6), Harvard Business Review, 1998, 80 , see generally 77-90. 
